\title{
Slurry Ice as a Cooling System on 30 GT Fishing Vessel
}

\author{
Alam Baheramsyah $^{1}$, Beni Cahyono ${ }^{2}$, Suganda $^{3}$
}

\begin{abstract}
Indonesian sea area is 5.8 million square kilometers and a coastline of $95.181 \mathrm{~km}$ has huge potential in the fisheries sector. In line with the need to further improve on the quality of the fish catch. One way to preserve fish is to use a slurry of ice. Slurry ice proved more effective preserving fishery products instead of using ice cubes. Ice slurry cooling system was designed and applied to the fishing vessel 30 GT. The cooling system uses a simple vapor compression system consists of five major components consisting of evaporator, condenser, compressor, and two pumps. In designing this system determined the type of refrigerant used in advance which type of refrigerant R-507a. Then do the design or selection of its main components. The design is only done on the evaporator. As for the other major components such as condensers, compressors, and pumps election in accordance with the specification of the power needed. After that dialakukan depiction of each system component. Then subsequently designing the laying of ice slurry cooling system components on a fishing vessel 30 GT. Through calculations using simple thermodynamic equations obtained cooling load on this system amounted to $32.06 \mathrm{~kW}$. Condenser with a power of $40 \mathrm{~kW}$. Compressor with power $12 \mathrm{~kW}$. Pump with capacity $10 \mathrm{~m}^{3} / \mathrm{h}$. With memepertimbangkan space left on the ship in the ice slurry system design on the main deck of the ship to the efficient use of space on board. The power requirements of the generator vessel increases due to the addition of ice slurry system components therefore do replacement generator into the generator with a power of $100 \mathrm{~kW}$ and penambahn fuel tank to $6000 \mathrm{~L}$.
\end{abstract}

Keywords — cooling system design, fishing boat 30 GT, load cooling, slurry ice

\section{INTRODUCTION}

I ndonesia is the largest archipelago country in the world that has a sea area that is very spacious. Indonesian sea area is 5.8 million square kilometers and a coastline of $95181 \mathrm{~km}$ has huge potential in the fisheries sector. In 2016 the Government of Indonesia through the Ministry of Maritime Affairs and Fisheries Indonesia set a production target fish catch reached $2.4 \%$ to 6.45 million tonnes. In line with the need to further improve on the quality of the fish catch.

To improve the quality of fish caught, we perform the processing and preserving fish. Preservation and processing of fish aims to prevent or stop the activity of substances and microorganisms that can cause spoilage (quality deterioration) and damage.

Preserving the traditional fishing vessels generally use ice cubes. This system is considered not to give maximum benefits because ice is hard and rough surfaces cause friction in fish that can cause damage to the fish that can bring down the price when the fish will be marketed. Then the cross-sectional area was relatively smaller cooling.

Currently there are alternatives to traditional systems which use ice blocks and much more effectively by using ice slurry. Slurry ice becoming a popular choice best for ice slurry performance is better than ice cubes to keep

Alam Baheramsyah, Department of Marine Engineering, Institut Teknologi Sepuluh Nopember, Surabaya 60111, Indonesia, Email : alam@its.ac.id

Beni Cahyono, Department of Marine Engineering, Institut Teknologi Sepuluh Nopember, Surabaya 60111, Indonesia, Email : cak_beny@yahoo.com

Suganda, Department of Marine Engineering, Institut Teknologi Sepuluh Nopember, Surabaya 60111, Indonesia, Email : - the quality of the fish. Ice slurry as cooling the fish could keep no air between fish and ice, thus cooling the fish become faster because the surface area of the contact area is larger and slower growth of bacteria that makes extending the freshness of the fish. Another function of the cooling ice slurry cooling time fish are fish three times faster than ice cubes to lower the temperature of up to $-2^{\circ} \mathrm{C}$. Sea water is a basic ingredient of ice slurry would be better to maintain the durability of the fish because it contains elements chlorine $(\mathrm{Cl})$, which can kill the bacteria that cause decay.

The cooling system uses a slurry of ice in developed countries is usually mounted on a large-sized fishing boats. But in Indonesia in general, fishermen were still using fishing boats with $\leq 30$ GT. Therefore in this research seeks to design the system on a fishing vessel with a capacity of 30 GT.

\section{LITERATURE REVIEW}

\section{A. Vapour Compression System}

Compression refrigeration cycle to take advantage of the fact that the high-pressure fluid at a certain temperature tends to be cooler if allowed to expand. If the change in pressure is high enough, then the gas is pressed will be warmer than the cold outside source (eg. outside air) and gas that expands would be colder than cold temperatures desired [1].

\section{B. Vapour Compression Refrigeration System} Performance

By ignoring the kinetic energy and potential energy tesebut working parameters can be calculated as a function of the enthalpy at every level of the state as in Figure 1 [10]. 


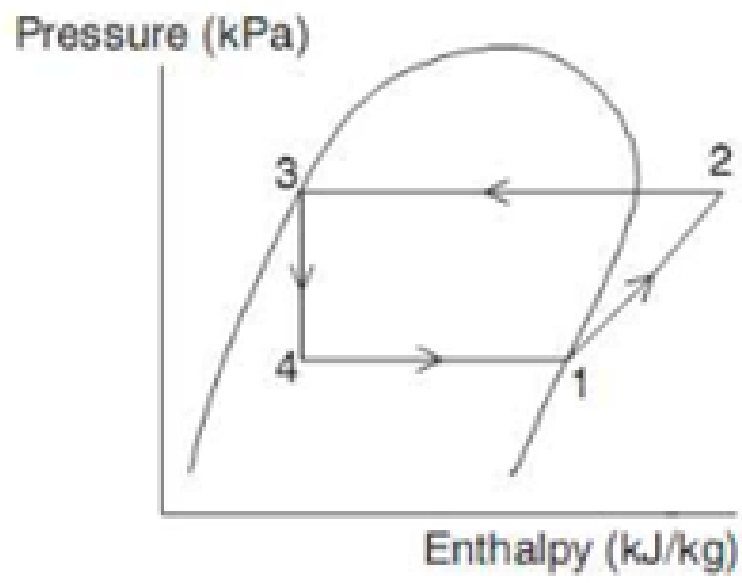

Figure. 1. Diagram of pressure against enthalpy

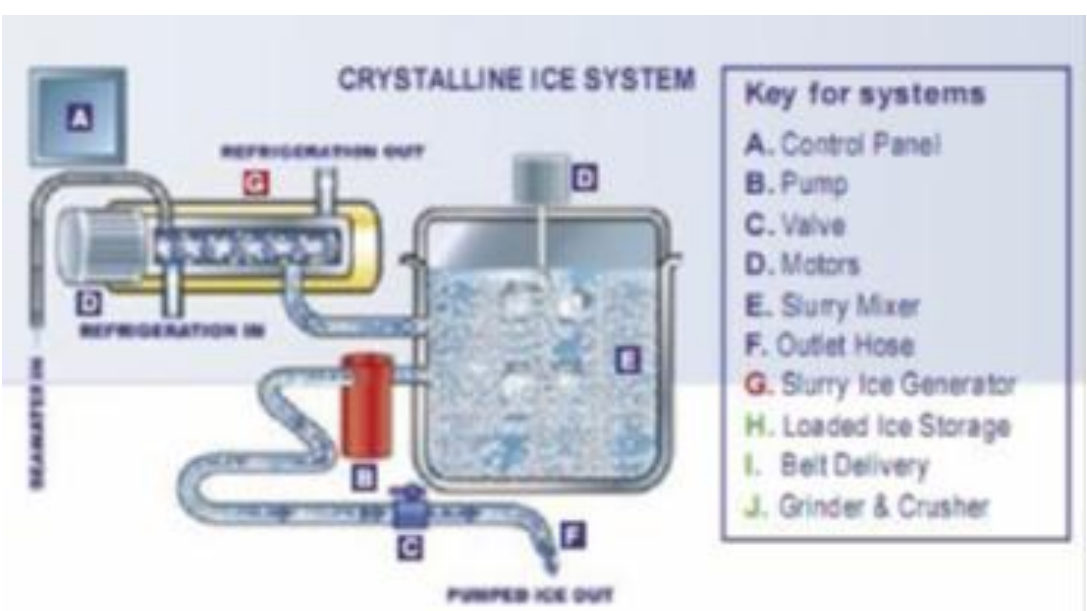

Figure. 2. Crystalline ice machine ice slurry system

\section{Work Compression}

Work shown by the compression process 1-2. By using the energy balance equation, then the work of compression can be formulated by the following equation [5]:

$\mathrm{Wcomp}=\mathrm{m}(\mathrm{h} 2-\mathrm{h} 1)$

\section{Capacity Refrigeration}

Refrigeration capacity indicates the amount of heat taken by refrigerant from the environment. This process occurs in the evaporator and is shown by the 4-1, and can be formulated by the following equation [3]:

$\mathrm{QE}=\mathrm{m}(\mathrm{h} 1-\mathrm{h} 4)$

\section{Coeffisien of Performance}

COP value indicates the efficiency of a refrigeration machine [4]. This value is obtained from the comparison between the work of compression refrigeration capacity [9], can be formulated as follows:

$\mathrm{COP}=\mathrm{Q}_{\mathrm{E}} / \mathrm{W}_{\mathrm{C}}$

\section{Slurry Ice}

Slurry ice is a solution consisting of water and ice crystals[2]. Slurry ice also didefinisakan as Finecrystalline Ice slurry is a slurry of ice with ice particles have an average diameter equal to or less than $1 \mathrm{~mm}$.
In general, ice slurry has the properties and physical characteristics as follows [11]:

- Solutions and solids with temperatures of up to $-15^{\circ} \mathrm{C}$.

- Can be made from the brine solution used below the freezing point with the cooling load at a temperature between $-2^{\circ} \mathrm{C}$ up to $-50^{\circ} \mathrm{C}$.

- Slurry ice will be a solution that has the properties and behavior are very different from the brine that is dissolving.

- It is a two-phase fluid is non-Newtonian at high ice fraction.

- Requires calculation of piping, pumps, heat exchangers, storage tanks and different.

D. Development of Ice Slurry Technology On Fishing Vessel

Seafish Industry is one of the developers of ice slurry Technology Seafish Industry developed two types of ice slurry producing system that is Crystalline Ice System and Ground Ice System [6]. Ice slurry producing system used in this research is similar to the system works Crystalline Ice System. In this system there Crystalline Ice System slurry ice generator which serves to produce ice slurry of sea water [7]. Slurry ice that has formed accommodated in the ice storage equipped with a stirrer [8]. Ice storage is connected to a pump that serves the ice slurry to fish storage. 


\section{METHOD}

Broadly speaking, the construction stage is divided into three stages. The first stage perform the calculations for the cooling load and the power of each component, and then do the design or selection menggmbar major components and dimensions of each major component, and then to the final step to make keyplan systems and image layout system on fishing boats $30 \mathrm{GT}$.

\section{A. Calculated Cooling Load}

Analyzing cooling load that must be taken by using a refrigerant heat exchanger or evaporator.

\section{B. Selection and Refrigerant System}

In the selection of the system used to note is compliance with the size of the vessel and therefore the system is to use simple vapor compression systems because of less use of the main components of the system. Then the selected type of refrigerant is because refrigerant that can operate at a low of temperature

\section{Design or Component}

For designing or selecting components performed thermodynamic calculations using simple.

\section{Design Principal Component System}

Designing major system components to determine the dimensions of each major component.

\section{E. Draw Keyplan System}

Designing the system and determine the laying of the main components on a fishing vessel $30 \mathrm{GT}$.

\section{F. Designing Slurry Ice Systems on Ships}

Applying ice slurry system design on the vessel and determine its placement on the ship.

\section{G.Conclusions and Recommendations}

To conclusion is the answer to the formulation of the problem and part of an important part of the discussion.

\section{RESULT AND DISCUSSION}

\section{A. Cooling Load Analysis}

Mass of sea water is also important in determining adjusted to the cooling load volume biggest hatch. The comparison between the amount of ice and fish is
$50 \%: 50 \%$, so the calculation of the mass of sea water to be cooled is:

$$
\begin{aligned}
\operatorname{Massa}\left(\mathrm{M}_{\mathrm{sw}}\right) & =\rho_{\mathrm{sw}} \cdot 75 \% \mathrm{~V}_{\text {palka }} \\
& =1024,12 \mathrm{~kg} / \mathrm{m}^{3} \cdot 6 \mathrm{~m}^{3} \\
& =6144,72 \mathrm{~kg}
\end{aligned}
$$

Then to determine the cooling load is met by the system is calculated by the following equation:

$$
\begin{aligned}
& \mathrm{Q}=M \frac{\left\lfloor C p_{\text {air }} \cdot\left(T_{\text {air }}-T_{\text {beku }}\right)+0.3 \cdot h_{f g}+0.3 \cdot C p_{\text {es }} \cdot\left(T_{\text {belu }}-T_{\text {slury }}\right)+0.7 \cdot C p_{\text {air }} \cdot\left(T_{\text {belu }}-T_{\text {slury }}\right)\right\rfloor}{t} \\
& \mathrm{Q}=M \frac{\left\lfloor C p_{w} \cdot(28-1.91)+0.3 \cdot h_{f s}+0.3 \cdot C p_{i} \cdot(2.5-1.91)+0.7 \cdot C p_{w} \cdot(2.5-1.91)\right\rfloor}{(14.3600)} \\
& \mathrm{Q}=32,06 \mathrm{KW}
\end{aligned}
$$

State-level R-507a refrigerant in the system operating conditions are as follows:

$$
\begin{array}{llll}
\mathrm{T}_{\text {eva }} & =-35^{\circ} \mathrm{C} & \mathrm{h}_{1} & =339,4 \mathrm{~kJ} / \mathrm{kg} \\
\mathrm{T}_{\text {cond }} & =38^{\circ} \mathrm{C} & \mathrm{h}_{2} & =389,2 \mathrm{~kJ} / \mathrm{kg} \\
\mathrm{P}_{\text {eva }}=1,408 \mathrm{bar} & \mathrm{h}_{3} & =254,9 \mathrm{~kJ} / \mathrm{kg} \\
\mathrm{P}_{\text {cond }} & =17,43 \mathrm{bar} & \mathrm{h}_{4} & =254,9 \mathrm{~kJ} / \mathrm{kg}
\end{array}
$$

Refrigerant mass flow rate of $0.21 \mathrm{~kg} / \mathrm{s}$. Then the energy balance equation melalaui work of the compressor and the heat removed through the condenser can be calculated as follows:

Compressor work:

$$
\begin{aligned}
\mathrm{W}_{\text {comp }} & =\mathrm{m} .\left(\mathrm{h}_{1}-\mathrm{h}_{2}\right) \\
& =0,21 \mathrm{~kg} / \mathrm{s} .(339,4-389,2) \mathrm{kJ} / \mathrm{kg} \\
& =-10,64 \mathrm{~kW}
\end{aligned}
$$

The value of this amount is negative, indicating the work carried out on the compressor.

The heat released in the condenser:

$$
\begin{aligned}
\mathrm{Q}_{\text {cond }} & =\mathrm{m} .\left(\mathrm{h}_{3}-\mathrm{h}_{2}\right) \\
& =0,21 \mathrm{~kg} / \mathrm{s} .(254,9-389,2) \mathrm{kJ} / \mathrm{kg} \\
& =-28,7 \mathrm{Kw}
\end{aligned}
$$

Coeffisien of Performance

$$
\begin{aligned}
\mathrm{COP} & =\frac{Q_{E}}{w_{c}} \\
& =24,06 / 10,64 \\
& =2,26
\end{aligned}
$$

TABLE 1.

SPECIFICATIONS REFRIGERANT USED

\begin{tabular}{cc}
\hline Parameter & Refrigerant \\
\hline Refrigerant & R-507a \\
\hline Evaporator Temperature $\left({ }^{\circ} \mathrm{C}\right)$ & -35 \\
\hline Condensor Temperature $\left({ }^{\circ} \mathrm{C}\right)$ & 38 \\
\hline Q evaporator $(\mathrm{kW})$ & 32,06 \\
\hline Q condensor $(\mathrm{kW})$ & 28,7 \\
\hline Mass flow rate refrigerant $(\mathrm{kg} / \mathrm{s})$ & 0,127 \\
\hline Compressor work $(\mathrm{kW})$ & 10,64 \\
\hline
\end{tabular}




\section{B. Design of Evaporator}

Evaporator on this system apart is also a heat exchanger where the formation of ice slurry. Dimensions evaporator is calculated in accordance with the capacity needs of ice slurry at $8 \mathrm{~m}^{3}$.

Calculation of the length of pipe evaporator done using the following equation:

$$
\mathrm{L}=\frac{Q_{\text {eva }}}{U_{o} . L M T D \cdot \pi \cdot d_{o}}
$$

$\mathrm{L} \quad=$ length of the tube evaporator is required $(\mathrm{m})$

Qeva = evaporator cooling capacity $(\mathrm{W})$

Uo = total heat transfer coefficient $\left(\mathrm{W} / \mathrm{m}^{2} \mathrm{~K}\right)$

LMTD = average temperature difference of fluid $(\mathrm{K})$

do = outer diameter of tube $(\mathrm{m})$

From the calculations, the pipe length $155 \mathrm{~m}$. The pipeline will be assembled around the sea water tank.

\section{Selection of Compressors}

Selection of the compressor should consider the type of refrigerant used, the labor market and the mass flow rate. Reciprocating compressors used types. In choosing a compressor that has been compressor power consumption approaching theoretical power requirement $10.64 \mathrm{~kW}$.

$$
\begin{array}{ll}
\mathrm{P}_{\mathrm{a}} & : 0,381 \mathrm{MPa} \\
\mathrm{P}_{\text {cond }} & : 1,46 \mathrm{MPa} \\
\mathrm{h}_{1} & : 353,7 \mathrm{~kJ} / \mathrm{kg} \\
\mathrm{h}_{2} & : 379,9 \mathrm{~kJ} / \mathrm{kg} \\
\mathrm{h}_{3} & : 243,7 \mathrm{~kJ} / \mathrm{kg} \\
\mathrm{h}_{4} & : 243,7 \mathrm{~kJ} / \mathrm{kg}
\end{array}
$$

The calculations for the compression ratio can be achieved compressors are as follows:

Compression ratio $=\frac{p_{\text {cond }}}{p_{\text {eva }}}=\frac{1,46}{0,38}=3,84$

Calculation of the mass flow rate by the compressor is as follows

$\mathrm{m}_{\text {ref }}=\frac{W_{\text {comp }}}{\left(h_{2^{\prime}}-h_{1^{\prime}}\right)}=\frac{10,64 k W}{(379,9-353,7) k J / k g}=0,131 \mathrm{~kg} / \mathrm{s}$

Based on the above calculation in accordance with the system compressor is a type $4 \mathrm{VES}-10 \mathrm{Y}$. Here are the specifications of the selected compressor is compressor 4 VES-10Y from the catalog Bitzer.

TABEL 2.

COMPRESSOR SPESIFICATION 4VES-10Y

\begin{tabular}{lccc} 
& \multicolumn{2}{c}{ COMPRESSOR SPESIFICATION 4VES-10Y } & VI \\
\hline Motor version & - & 1 \\
\hline Displacement at 1450 min-1 & $\mathrm{m}^{3} / \mathrm{hr}$ & 34,73 \\
\hline Number of Cylinder & - & 4 \\
\hline Oil charge & $\mathrm{dm}^{3}$ & 2,60 \\
\hline Weight & $\mathrm{kg}$ & 139 \\
\hline Pipe Connections (suction line) & $\mathrm{mm}$ & 28 \\
\hline Pipe Connections (discharge line) & $\mathrm{mm}$ & 22 \\
\hline Max. operating current & $\mathrm{ampere}$ & 19,9 \\
\hline Max. power consumption & $\mathrm{kW}$ & 12 \\
\hline
\end{tabular}

\section{Selection of Condenser}

The heat exchanger is selected as a condenser in this system is a kind of Shell and Tubes. Condenser selected in this system should be able to transfer heat $28.7 \mathrm{~kW}$. The data is then analyzed to determine the condenser heat transfer is desired. Through the above calculation is selected condenser condenser Alfa Laval CXP 142-XS$2 \mathrm{P}$ with a capacity of $42 \mathrm{~kW}$.

\section{E. Pump Selection}

Selection is done to fill the pump seawater into the seawater tank and to drain water into the tanks of seawater evaporator. In the selection of the pump to take into account is the capacity and pumping head. To fill the tank seawater is estimated to take 1 hour. It is necessary for the calculation in determining the capacity and the pump head with the following equation:

$$
\begin{aligned}
\mathrm{Q} & =\mathrm{V} / \mathrm{t} \\
& =8 \mathrm{~m}^{3} / 1 \\
& =8 \mathrm{~m}^{3} / \mathrm{h} \\
& =0,0022 \mathrm{~m}^{3} / \mathrm{s}
\end{aligned}
$$

Then to calculate the pump head is used equation :

Htot $=\mathrm{Hs}+\mathrm{Hp}+\mathrm{Hv}+\sum$ head losses

$$
\begin{aligned}
& =1,2+0+0+1,35 \\
& =2,55
\end{aligned}
$$

Then the selection seawater pump into the seawater tank and to drain sea water from seawater into the evaporator tank of Sili Pump catalog with the following specifications:

Brand of Pump : Sili PUMP

Type : 50CLZ-7A

Pump Capacity : $10 \mathrm{~m}^{3} / \mathrm{h}$ or $0167 \mathrm{~m}^{3} / \mathrm{min}$

Pump Head : $17 \mathrm{~m}$

Rotation : $2900 \mathrm{RPM}$ 
Each depiction 2D Components The major components that have been designed and then made twodimensional depiction to indicate the size of each of each component. 2-dimensional image of each component is attached in the appendix of this research.

\section{F. Making Keyplan}

Keyplan system is made to understand the working of ice slurry cooling system. The system is divided into two grooves of the first groove and the second refrigerant flow of sea water.

\section{- Refrigerant Flow}

At first this flow of refrigerant in the vapor phase in the system increased its pressure using a compressor which is then supplied to the condenser. Once inside the condenser, refrigerant heat is then absorbed and transformed her into a liquid phase. Refrigerant is then lowered his pressure using needle valve so that the refrigerant temperature reaches minus. This refrigerant is then used to mendingingkan sea water in the evaporator or ice slurry tank formation. The liquid refrigerant which is inside the evaporator after absorbing heat from seawater back into the vapor phase and then goes back into the compressor.

\section{- Sea Water Flow}

In this process first of all sea water is pumped into the tank of sea water until it reaches maximum capacity. Then the sea water is pumped into the tank of ice slurry formation. The seawater in the tank and then decreased temperature due to the heat released. Then the sea water in the tank to speed cooling and prevent clotting does not occur then used auger shaft fitted with scraper moving inside the tank. Then after the sea water turns into ice slurry tank valve is opened to drain the ice slurry into hatch.

\section{G. Design Slurry Ice Systems on Ships}

In designing these systems need to consider the effectiveness of the laying of the system components. Therefore, the component placed on the vessel so as not to reduce the space hatch of the ship. The component is placed such that it becomes ice slurry cooling system. Components of the system: pump and sea water tanks placed on starboard side of the ship. The pump is placed near the rim to minimize pump head loss. Evaporator or tubes forming a slurry of ice placed between the hatch so that the distribution of ice slurry easier to put into hatch. As for the condenser and compressor are placed at the side of the ship portside in order to balance the weight of ice slurry systems on ships.

After designing the ship, the ship needs from the generator increases. Generator power requirements increase, the ship also affects the fuel tank capacity is greater. Therefore the calculation of the addition of generators and fuel tanks.

\section{- Calculation Addition Genset Ships}

Genset ship initially had a power of $5 \mathrm{kVA}$ or the equivalent of $4 \mathrm{~kW}$.Then after the addition of ice slurry systems on board the ship with the generator requires greater power.

$>$ Two pieces each pump power of $1.5 \mathrm{~kW}$ multiplied by the efficiency increase of 0.95 so that two pumps require electrical power of 2.85 $\mathrm{kW}$.

$>$ One piece condenser power $40 \mathrm{~kW}$ multiplied by 0.95 to $1 \mathrm{pc}$ efficiency condenser requires power $38 \mathrm{~kW}$.

$>$ One compressors powered $12 \mathrm{~kW}$ multiplied by 0.95 to 1 efficiency compressors require a power of $11.4 \mathrm{~kW}$.

$>$ One piece evaporator efficiency increase powerless 32.06 multiplied by 0.95 to 1 fruit evaporator requires a power of $30.46 \mathrm{~kW}$.

After each major component of the system are calculated and summed then obtained additional generator power requirements by $82,71 \mathrm{~kW}$. Then the generator vessel was later replaced with brand Cummins gensets with type C125-D5 with a power of $100 \mathrm{~kW}$. Specifications and images generator on a ship described in Appendices.

- Calculation Addition of Fuel Tank

Once the generator is replaced automatically ship fuel tank needs also increase. Therefore, the fuel tank at its beginning of 5000 liters to 6000 liters. The addition of the tank volume listed in the appendix. 
International Journal of Marine Engineering Innovation and Research, Vol. 1(3), Jun. 2017. 136-142 (pISSN: 2541-5972, eISSN: 2548-1479)

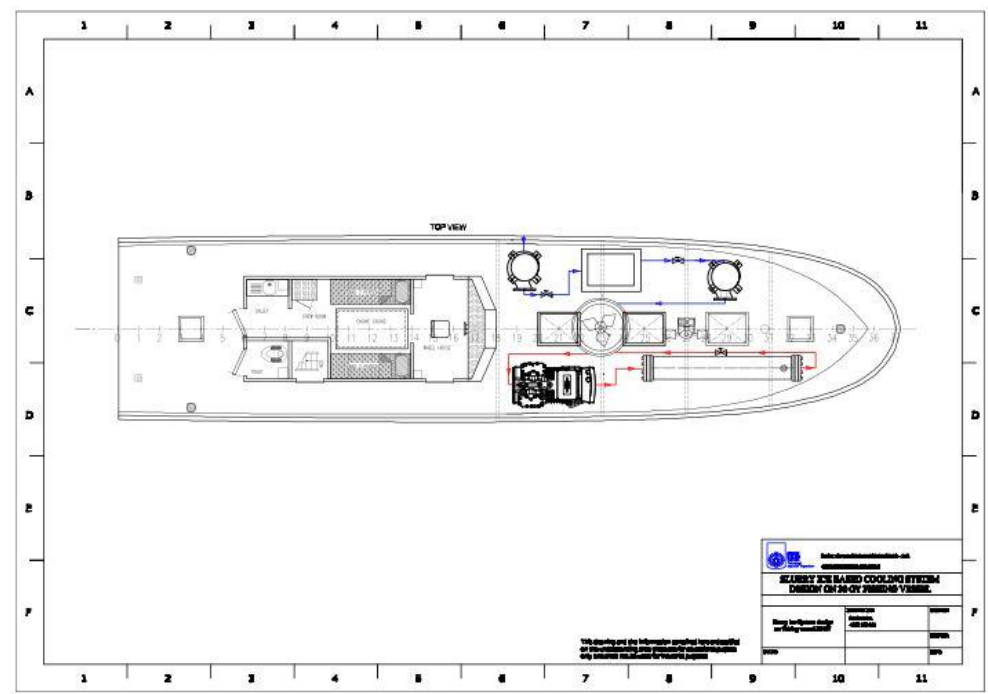

Figure 3 Keyplan cooling system slurry ice

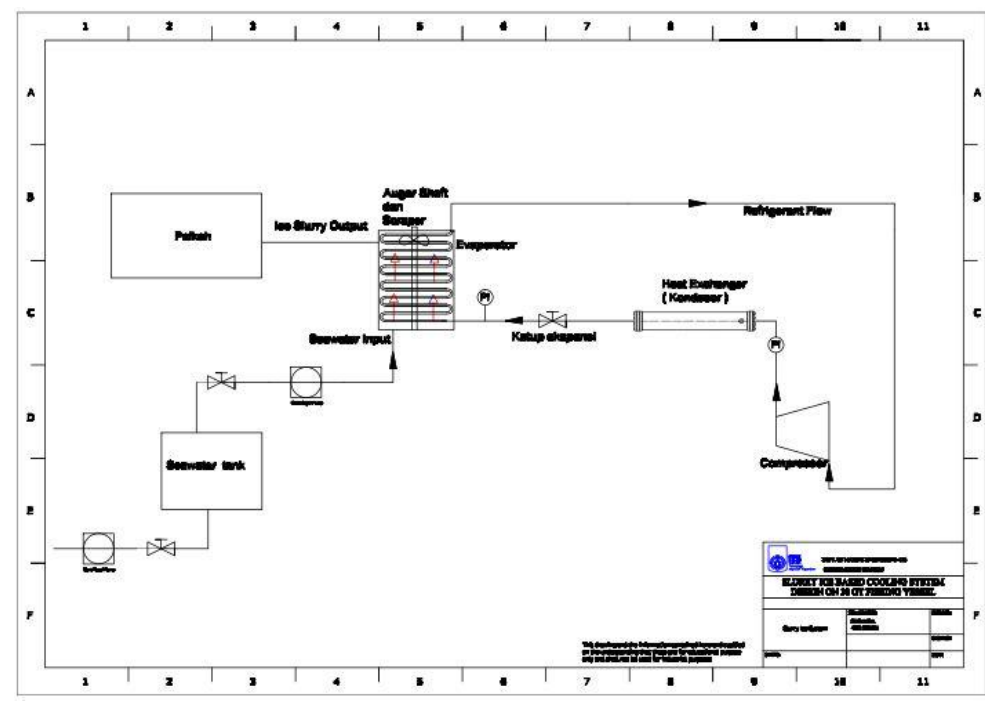

Figure 4 Ice Slurry Systems Design On Fishing Boat 30 GT

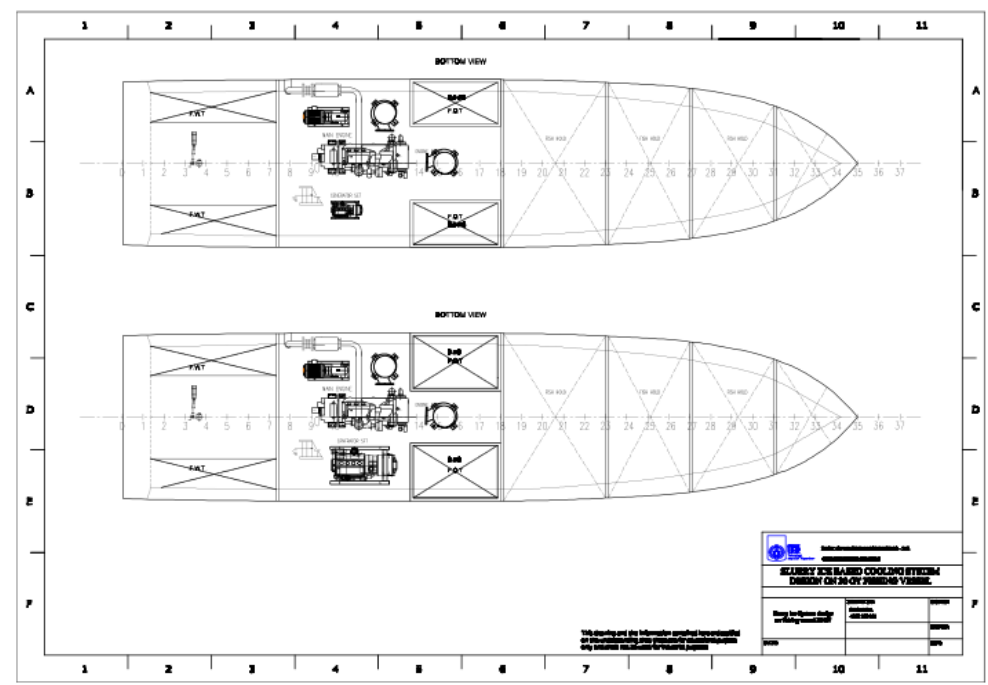

Figure 5 Bottom View After Calculation Generator Set and Fuel Oil Tank 


\section{CONCLUSION}

Based on analysis, can make conclusion that are:

1. The system used in this research is the simple vapor compression systems using R507a refrigerant.

2. The main component is designed evaporator which also serves as an ice slurry formation tank with capacity $8 \mathrm{~m}^{3}$ with the cooling load requirement of $32.06 \mathrm{~kW}$.

3. The main components are selected based on power requirements such as condensers, compressors, and two pumps. Condenser selected manifold shell and tube type Alfa Laval CXP 142-XS-2P with a power of $40 \mathrm{~kW}$. Then the selected manifold reciprocating compressor with Bitzer type 4VES-10Y with $12 \mathrm{~kW}$ power. And for the pump are selected with the type of Sili Pump CLZ 50-7A with capacity $10 \mathrm{~m}^{3} / \mathrm{h}$ and had the pump by $17 \mathrm{~m}$.

4. Based on consideration the ice slurry system design on the main deck of the ship to the efficient use of space on board.

5. The need for power from the generator vessel increases due to the addition of ice slurry system components therefore do replacement generator into the generator with the type Cummins C125-D5 with a power of $100 \mathrm{~kW}$.

6. The need for a fuel tank increases due to the replacement of the generator vessel from the initial capacity of $5000 \mathrm{~L}$ to $6000 \mathrm{~L}$.

\section{REFERENCES}

[1]. Arismunandar, W. dan Heizo Saito. 2002. Penyegaran Udara. PT. Pradnya Paramita, Jakarta

[2]. Dossat, RJ. 1976. Principle of Refrigeration

[3]. Handoko, K. 1981. Teknik Lemari Es. PT. Ichtiar Baru, Jakarta.

[4]. Hartanto, B. 1982. Teknik Mesin Pendingin. BKPI, Tegal.

[5]. Holman, J.P. 1988. Perpindahan Panas (Heat Transfer). Erlangga, Jakarta.

[6]. Ilyas, S. 1983. Teknologi Refrigerasi Hasil Perikanan Jilid I, Badan Penelitian dan Pengembangan Pertanian. CV. Paripurna, Jakarta.

[7]. Ilyas, S, 1993. Teknologi Refrigerasi Hasil Perikanan Jilid II, Badan Penelitian dan Pengembangan Pertanian. CV. Paripurna, Jakarta.

[8]. Listiyani,P. 2009. Perancangan Mesin Pendingin Pada Kapal Penangkap Ikan Dengan Kapasitas 30 Gross Tonage. Institut Teknologi Bandung, Bandung

[9]. Stoecker, W.F. dan Jerold, J.W. 1994. Refrigerasi dan Pengkondisian Udara Edisi kedua. PT. Erlangga, Jakarta.

[10]. Sumanto. 2001. Dasar - dasar Mesin Pendingin.Andi, Yogjakarta

[11] A. Z. M. Fathallah, W. Busse, and F. R. Clausthaldi, "Fluid Flow Analysis of Jacket Cooling System for Marine Diesel Engine 93 Kw," Int. J. Mar. Eng. Innov. Res., vol. 1, no. 2, Mar. 2017. 